$\xi=-1$

\title{
The impact of globalization on Workers: an Analysis of Nigerian Public Service
}

\author{
Aminu Mohammed Lawan ${ }^{* 1}$, Razlini Mohd Ramli \\ ${ }^{1,2}$ School of Social Sciences, Universiti Sains Malaysia (USM) 11800, Pulau Pinang, Malaysia. \\ *Corresponding author E-mail:aminuhadi2@gmail.com
}

\begin{abstract}
Globalization is the increasing interaction of peoples, states or countries through the growth of the global trade, international flow of capital, ideas and culture. The paper discusses how privatization of public corporations and invention of information and communication technology (ICT) lead to the retrenchment and casualization of public servant. The aim of this study is to examines the impact of globalization on the public servant in Nigeria. The methodology involves the use of secondary data, through a systematic literature review which entails the document analysis of related matters. The findings reveal that globalization infringes on the right of a public servant by making them vulnerable without job security. The paper concludes that government must stop unfair labor practice such as retrenchment and casualization of workers, and improve good working conditions to make public servant more productive.
\end{abstract}

Keywords: Globalization; Nigeria; Public Service; Public Servant; Workers

\section{Introduction}

Globalization is the increasing interaction of peoples, states or countries through the growth of the global trade, international flow of capital, ideas and culture. According to Martens and Raza (1) globalisation is the more global flow of products and facilities, monetary assets, information and persons. Also, there are technical advancement, greater transnational social interactions, facilitated by the free trade of more different goods and by tourism and immigration, variations in the political scenery and environmental significances.

According to Cerny (1999 in Sezen, 2001:1) globalization is "the convergence of economics and politics across borders into single dominant model, a variant of liberal capitalism aligned with neoliberal politics" or "the intersection of different form of both convergence and divergence."(2)

The globalization effect on Nigeria's economic development is negative, due to the fact that the country operates as mono economy. This is to say that it solely relies on the export of petroleum product which account for about $90 \%$ of its national income. Presently it imports finished petroleum product from abroad which stand for almost $80 \%$ into the country, because of its malfunctional refineries and high demand of petroleum product. The economy was not developed since it relies more on import than exports. For instance, the country's crude petroleum product exports in 1960 stand as 2.6\%. While increased to $25.4 \%$ in 1965 and in 1970 the figure stands as $57.5 \%$. It also rose to $98.7 \%$ in 2000 , it then dropped to $96.4 \%$ by the year 2010 (Sede \& Izilein, 2013 in (3) The study shows that globalization encourage economic growth through complementary reforms indirectly. the findings also indicate globalization ensures economic growth, whether the impact is advantageous, rest on the level of revenue of nation-states. High and medium income states have advantage of globalization than low income nations (4).
However, this study discusses the impact of globalization on public sector workers in Nigeria. Nigeria is the largest country in Africa with the estimated population of 180 million peoples it government implement the policies of globalization by privatizing many public corporations to private individuals since 1999 . This include privatization of Nigeria telecommunication company (NITEL), National electric power authority (NEPA), National fertilizer company of Nigeria (NAFCON) and many other government corporate bodies. This globalization policy has seriously affect the plight of workers in the above-mentioned enterprises which include job loss. Globalization is a worldwide phenomenon that affect almost every sector in the world including public service. It was spread globally through the Bretton wood agencies, this include world bank and international monetary fund (IMF) that grant soft loans to benefiting countries with strict conditions. This include removal of subsidies, deregulation, devaluation of currency, privatization and commercialization of public corporation, retrenchment of workers and rationalization of public service which lead to the casualization of labour.

Several administrations in Nigeria have taken diverse actions within the background that their existing control mechanism was proficient of achieving change. To this effect, panels were established in numerous cases to identify the disorder of these public corporations and make suitable remedies. Ill-advisedly, the reports of these panels did not at all aid the matter (Anyanwu, 1999 in (5). The Babangida administration in an anxious bid to change the economy out of the stagnations, released the contentious Structural Adjustment Programme (SAP), on the denationalization of public corporations to re-establish productivity in them and relieve the government's declining economic resources. This required the Decree No 25 1988, but whether the declaration worked or not, will need appropriate analysis (5).

Going by the levels of fundamental clarifications of the difficulties that led to the privatization decree, denationalization is possible to have its most positive effects on the political and economic struc- 
tural levels of the country. With a verdict to surrender ownership and management, there is a reasonable chance that the exhausting effects of political, bureaucratic and legislative lethargies would be cured and eliminated (Zayyad, 1992 in Ikechukwu,2013). Furthermore, in fulfilment of their selfishness, holders and managers of denationalized enterprises might become more imaginative, more resourceful, more self-controlled, answerable and fruitful now ever than. In addition, where this is not forthcoming, they fold up (Salako, 1999 in (5).

This anticipation however, does not spread to enterprises not sold. The hope for commercialized enterprises is even thinner because nothing is expected to modification except of course the high amount charges and rates. The experience of the Nigerian Airways in current times whose fares increased by 33 percent in the first occurrence and then 100 percent in the second can be used to support this claim.

However, the introduction of new technology innovation that is the use of information and communication technology (ICT) render workers worthless because most of the office work are been done by computer with a little effort of human being.

The objective of this study is to explore how globalization impact on public sector workers negatively, through the privatization of public corporation which lead to the retrenchment and disengagement of a lot of public servants, also render many of them to be casual or contract staff. The first section introduces the paper, section two reviews the relevant literature on the subject matter, section three covers the methodology, and the last section concludes the paper.

\section{Literature Review}

This section systematically reviews the relevant literature of the study on the impact of globalization on public service.

\subsection{The Impact of Globalization on Public Service}

According to Martens and Raza (1) globalization is "the growing interaction of markets, nation states and the spread of technological advancement, receding geographical constrains on social and cultural arrangements, the increased dissemination of ideas and technologies, the threat to national sovereignty by transnational actors, or the transformation of economic, political and cultural foundations of societies"(Martens and Raza, 2010:280). Moreover, Public Service define as a service which is provided by the government to people living within its jurisdiction, either directly (through the public sector) or by financing provision of services. While public servant is a government employee or official who render service to the people.

However, globalization imposed its policies on the nation states to break the barrier of trade and allow the international flow of capital for foreign direct investment (FDI) and privatize public enterprises. According to Robertson (2007:2) "globalization is the transmission of ideas; the intermingling of culture; the preservation or loss of national identity; exchanges of technology, capital, workers and products across borders; and the role of international non-governmental organizations"(6).

Furthermore, globalization affects workers not only through wages, but also through employment. Trade liberalization is associated with job losses in formally protected sectors. It is also associated with the replacement of permanent workers, who have a more privileged status, by temporary and casual workers, who enjoy fewer benefits (7).

Feingold (2013) in his study discovers that between 2008-2012 forty countries have introduced reform programs that eliminate or reduce employment protection for formally employed workers, and globally only $7 \%$ of workers in the formal economy are in an independent union. The decline in unionization, deregulation and the deterioration of the bargaining power has resulted in only not increased in wage inequality but also in increased informal employment worldwide(8).

Obadan (2003) however, noted that the Bretton Woods Institutions (World Bank and International Monetary Fund, IMF) wield tremendous authority in a majority developing countries that depends on their loans. Countries requiring debt rescheduling must adopt structural adjustment Programme that are mainly drawn up in the Washington institutions. SAPs are used to undermine states macro-economic plans in addition, it currently includes societal strategies and organizational matters for instance a denationalization, monetary policy, governance and cooperation regulations. The instrument for credit distribution restricted on such plans, has been the core mechanism driving and undermining the economic sovereignty of most developing states. And often times the SAPs policies recommendations has been the tool compelling the policies mores of the indebted developing nations to liberalization, denationalization, deregulation, casualisation, job loss and absence of the nations from economic activities (9).

Todaro (2007) added that loan conditionality has thus, been the major mechanisms for global spreading of the Macroeconomics policy packages that are favoured by governments for the developed world. He noted with illustration that the Uruguay Round Negotiations greatly expanded the powers of the General Agreement on Trade and Tariffs (GATT) structure with agreement under the GATTs replacement body - World Trade Organization (WTO) have introduced corrections in some parts that go outside the remit of its predecessor GATT, together with rational possessions privileges, facilities, agronomy in addition to occupation related venture dealings.

Because of numerous studies, the treaty that developed from the Uruguay round creating the WTO has been an uneven pact and the WTO arrangements and systems are weighted against and capacity of most developing countries to make an independent decisions and policies. That the new agreement of required domestic location and policies of members states to fall in line further compromise the sovereignty of most developing countries(10) in (11). Obaseki (2000:29) argues that "the problem of labour market amalgamation similarly spread over to Nigeria. Moreover, numerous extremely trained Nigerians have travelled to other African states wherever their services are needed. This pattern follows what has been recognized in other sections of the world. The problem with workers relocation as it touches Nigeria is that vastly trained staffs that are limited in stock in the nation are migrating in pursuit of greener postures"' (12).

Base on the study, Danesi (13) discovers that globalization impacts on workers on casual basis, are discriminated in terms of pay and freedom to associate in work place. It suggests the need to review the existing labour to protect the vulnerable groups of workers.

Anugwom (14) discover that the effects of globalisation is negative to the employees in the self-proclaimed 'semi-skilled' class. Therefore, capitalist globalisation, opposing to the regularly- kind effects credited to it, has deteriorated relatively to progress condition of employees in the building engineering in Nigeria. This article demands for consideration in regulating the actions of Transnational Corporations (TNCs) with implementation of minimum ILO ethics in affiliate states, particularly in the emerging countries which they emphasise more on foreign direct investment instead of protecting their workers and sovereignty.

Meanwhile, Roughly the damages of temporary employees suffered as counted by (15) includes: Dreadful little salaries; Poor health services or stipends; Absence of employment safety or advancement at work; absence of leave or its grant; No right to form a union or peaceful assembly; Absence of death benefit or accident coverage of job; absence of joint negotiating treaty and collective bargaining; Non availability of adequate information about the number of casual employees.

Moreover, the economic structure of the third world countries Nigeria inclusive is not strong to adopt globalization policies because of hostile business environment which is difficult to operate. 
employees (temporary) disregarding their right to form the union or association.

\section{Conclusion}

Globalization stand as a stumbling block to the development of developing countries like Nigeria because of its harsh policies imposed on those nation states to strictly follow. Such policies are privatization of public enterprises which breeds the retrenchment and job loss to the public servant, and casualization and vulnerability of work. The paper concludes that globalization impacted negatively on Nigerian public servants because many employees losses their jobs due to the policies of denationalization of public enterprises and adoption of new technology of Information and Communication technology, ICT. This paper is limited to globalization aspect of privatization of public enterprises and the innovation of new technology, i.e. Information and communication technology, ICT.

As Ikechukwu (2013:5-6) observed "If privatization is carried out with sincerity of purpose, almost every group will come out ahead as a result of divestiture. Workers will be shareholders. Consumers will be better off because of better services. New graduates and the unemployed will get jobs because of expansion. Government will be relieved of the burden of subsidies. Investors will gain investment opportunities. Ultimately, the public (both foreigners and nationals) will be free to pursue any private economic interest'"(5).

Therefore, the paper recommends for more studies in the area of globalization effects on public sector workers in Nigeria, because most of the existing literature covers the impact of globalization on private sector employees.

\section{Acknowledgment}

This research was supported by the Tertiary Education Trust Fund (TETFund) Nigeria.

\section{References}

[1] Martens P, Raza M. Is globalisation sustainable? Sustainability. 2010;2(1):280-93

[2] Sezen S. The Impact of Globalization on the Organization of Public Administration: Turkish Case

[3] Turkish Public Administration Annual. 2001;27:26

[4] Agbarha EK, Peter SA. Globalization And Economic Growth in Nigeria: A Cointegration Approach. Journal of International Business and Economics. 2017;5(1):105-13.

[5] Samimi P, Jenatabadi HS. Globalization and economic growth: Empirical evidence on the role of complementarities. PloS one. 2014;9(4):e87824.

[6] Ikechukwu O. Privatization of public enterprises in Nigeria. Developing Country Studies. 2013;3(3):1-6.

[7] Robertson R. Globalization and Working Conditions: A Guideline for Country Studies

[8] Unpublished, World Bank, WashongtonDC. 2007:35.

[9] Rama M. Globalization and Workers in Developing Countries

[10] Development Research Group, world Bank, Washington Dc. 2003:55.

[11] Feingold C. Building Global Worker Power in a Time of Crisis. New Labor Forum. 2013;22(2):45-50.

[12] Obadan M. Globalization and the Nigeria Economy. CBN Economic Review. 2003;38.

[13] Todaro S. Understanding Globalization: The National Economy: A Keynesian Myth. London: Class. 2007.

[14] Charles MV, Mark PO. Globalization And Its Effect In Nigeria Public Service. Journal of Law, Policy and Globalization

[15] 2013;20:10.

[16] Obaseki PJ. Globalization and the Nigerian economy. Central Bank of Nigeria Economic and Financial Review. 2000;38(2):17-33.
[17] Danesi RA. THE CHANGING NATURE OF WORK: CAUSES AND EFFECTS ON EMPLOYMENT RELATIONSHIPS IN NIGERIA. unpublished Paper. 2015:32.

[18] Anugwom EE. Globalisation and labour utilisation in Nigeria: evidence from the construction industry. Africa Development. 2007;32(2).

[19] Okougbo E. Strategic issues on the dynamics of industrial relations: Theory and practice: Wepoapo Enterprises; 2004.

[20] Osagie R. Globalization and human resource development in Nigeria. American Journal of Social and Management Sciences. 2011:217-9.

[21] Ahearn RJ. Globalization, Worker Insecurity, and Policy Approaches

[22] Congressional Research Service. 2012:16.

[23] Ashaver BT. Poverty, Inequality and Underdevelopment in Third World Countries: Bad State Policies or Bad Global Rules. IOSR Journal of Humanities and Social Science (IOSR-JHSS), 15 (6). 2013:33-8.

[24] Onyeonoru I. Globalisation and industrial performance in Nigeria. AFRICA DEVELOPMENT-SENEGAL-. 2003;28(3/4):36-66.

[25] Okafor EE. Globalisation, Casualisation and Capitalist Business Ethics:

[26] A Critical Overview of Situation in the Oil and Gas Sector

[27] in Nigeria

[28] Journal of Social Sciences

[29] 2007;15(2):10. 